\title{
Preparation of tambacu protein concentrates using different methodologies
}

\section{Elaboração de concentrados proteicos de tambacu a partir de diferentes metodologias}

\author{
Natieli Inácio Fernandes; Claucia Aparecida Honorato²; Gabriela Cristina Ferreira \\ Bueno1; Maria Luiza Rodrigues de Souza33; Elenice Souza dos Reis Goes²*
}

\section{Highlights}

Tambacu filleting residues were used to make products with a high protein content. Defatting with ethanol after raw material dehydration was efficient and cheap.

Removal of lipids reduces odour and taste of fish in a tambacu protein concentrate.

\begin{abstract}
The aim of this study was to develop methodologies to obtain fish protein concentrates from tambacu filleting residues, characterize their physical-chemical composition and evaluate their sensory profile. Concentrates were prepared by one of three methodologies: cooking of the raw material and subsequent drying (FPC1); cooking, drying, lipid removal with ethanol at $70^{\circ} \mathrm{C}$ and final drying (FPC2); and three washing steps of the raw material with ethanol at $70^{\circ} \mathrm{C}$ and drying (FPC3). FPC2 had a lower final yield (15.5\%) and chroma $a^{*}(1.77)$ and chroma $b^{*}$ values (14.12) but higher moisture $(5.22 \%)$ and protein content $(80.39 \%)$ and luminosity (74.97), in addition to having the weakest fish taste compared to FPC1 and FPC3. FPC1 had the strongest odour, darkest colour, and strongest fish taste compared to FPC2 and FPC3. Ash, pH values, and water activity were not different between the concentrates. It is concluded that the methodology where lipid removal steps are carried out after cooking and drying (FPC2) is more effective for the removal of lipids and deodorization of tambacu protein concentrate.
\end{abstract}

Key words: Chemical composition. Ethanol. Utilization of residues. Lipid removal steps.

\section{Resumo}

Este trabalho teve por objetivo desenvolver metodologias para a obtenção de concentrados proteicos de pescado a partir de aparas da filetagem de tambacu, caracterizando sua composição físico-química e perfil sensorial. Foram utilizadas três metodologias: cozimento da matéria-prima e posterior secagem

1 Aquaculture Engineers, Faculty of Agricultural Sciences, Universidade Federal da Grande Dourados, UFGD, Dourados, MS, Brazil. E-mail: nati_if@hotmail.com; gabrielacfbueno@gmail.com

2 Profas Dras, Faculty of Agricultural Sciences, UFGD, Dourados, MS, Brazil. E-mail: clauciahonorato@ufgd.edu.br; elenicesreis@yahoo.com.br

${ }^{3}$ Profa $^{a} \mathrm{Dr}^{a}$, Department of Animal Science, Universidade Estadual de Maringá, UEM, Maringá, PR, Brazil. E-mail: mlrsouza@uem.br

* Author for correspondence

Received: Aug. 16, 2021 - Approved: Nov. 18, 2021 
(CP1), cozimento, secagem, deslipidificação com etanol a $70^{\circ} \mathrm{C}$ e secagem final (CP2) e três lavagens da matéria-prima com etanol a $70^{\circ} \mathrm{C}$ e secagem (CP3). O CP2 apresentou o menor rendimento final $(15,5 \%)$, porém maior teor de umidade $(5,22 \%)$, proteína $(80,39 \%)$ e luminosidade $(74,97)$, além de menores médias para croma $a^{*}(1,77)$, croma $b$ * $(14,12)$, além de sabor de peixe mais fraco comparado aos CP1 e CP3. O CP1 apresentou odor mais forte, cor mais escura e o sabor de peixe mais forte em relação ao CP2 e $\mathrm{CP} 3$. Os valores de $\mathrm{pH}$ e atividade de água não foram diferentes entre os concentrados. Conclui-se que a metodologia de deslipidificação após o cozimento e secagem (CP2) é mais eficaz para a remoção dos lipídeos e desodorização do concentrado proteico de tambacu.

Palavras-chave: Aproveitamento de resíduos. Composição química. Deslipidificação. Etanol.

\section{Introduction}

In 2020, Brazil produced 802,930 tons of farmed fish, an increase of $5.9 \%$ compared to the previous year; $34.71 \%$ of the total production is native fish (Associação Brasileira da Piscicultura [Peixe BR], 2021). One of the fish produced is tambacu, the result of crossing tambaqui (Colossoma macropomum) females with pacu (Piaractus mesopotamicus) males. According to Instituto Brasileiro de Geografia e Estatística [IBGE] (2016), this hybrid accounted for $8.7 \%$ of fish farming production in 2016, reaching a total of $42,298.5$ tons.

The growth of aquaculture production has resulted in the generation of large quantities of fish waste, mainly in industries, because waste that is not used is usually disposed of via landfill, dumping at sea or incineration (Dao \& Kim, 2011). The lack of an appropriate destination for waste generated by processing is considered one of the main problems of the processing chain (Oetterer, Galvão, \& Sucasas, 2014). Fish residues are composed of the head, carcass, viscera and skin, and are obtained in processes involving filleting, also including fish too small for commercial use (Vidotti, 2011). In the production of fillets, only about $35 \%$ of the fish is used, and $65 \%$ of the live weight is discarded during the filleting process (Fonseca, Frare,
D'Avila, \& Edwiges, 2020). The nutritional value of these residues, rich in proteins and polyunsaturated fatty acids, encourages the development of products for human food (Monteiro et al., 2014).

An alternative for adding value to processing residues is the elaboration of fish protein concentrates. This type of product contains an average of $75 \%$ protein and has emerged to meet low cost requirements, easy digestibility and storage, besides not requiring refrigeration, allowing its inclusion in embedded or formulated foods (Souza et al., 2010). The addition of fish protein concentrates to food products with a high carbohydrate and low protein content nutritionally enriches the product, also stimulating the consumer to eat fish even if indirectly (Coradini et al., 2015).

Fish protein concentrates can be conceptualized as dehydrated and ground products with a variable protein content, which may or may not have fish flavour and aroma, depending on the method used to their obtention (Ordóñez et al., 2005). Fish protein concentrates can be divided into three types: type A, defined as a white or lightyellow powder, without odour, with a protein content of $60-90 \%$ and maximum fat content of $0.75 \%$; type $B$, yellow or greyish, relatively deodorized, with up to $3 \%$ fat and $65 \%$ protein; 
and type $\mathrm{C}$, with odour, without limits for fat and with a minimum of $60 \%$ protein (Ordóñez et al., 2005). To obtain a type A concentrate, the lipids must be removed, which can be achieved by extraction in an alkaline medium or by treatment with organic solvents such as isopropanol or ethanol (Cândido, Nogueira, \& Sgarbieri, 1998). The manufacture of fish protein concentrates has a high cost due to successive extraction operations with organic solvents to degrease the final product (Jesus \& Almeida, 2011).

Although there are many fish protein isolation methods, they all share a common step, in which all non-protein parts (water, skin, bones, and especially lipids) are removed by solvents and precipitated to obtain protein at an isoelectric point $\mathrm{pH}$ between 5.2 and 5.5 (Trinh, Nguyen, Le, \& Le, 2017). Thus, the strategy for removing lipids from fish protein concentrates needs to be addressed by exploring different extraction methods. According to Ogawa and Maia (1999), ethanol has the function of dehydrating and isolating fat from meat. To obtain a tambacu protein concentrate that presents a low concentration of lipids and a consequently neutral taste and odour, methodologies for the extraction of lipids using ethanol were studied in this work. Several studies have developed methodologies for obtaining fish protein concentrates (Akhade, Koli, Sadawarte, \& Akhade, 2016; Ikasari \& Wijaya, 2021), but there studies have been based on tambacu, a fish with the potential for cultivation in Brazil.

Strategies for the use of fish processing residues of interest in the aquaculture chain are important to provide sustainable production, and tambacu protein concentrates could be an alternative for inclusion in food products. Thus, the aim of this study is to develop methodologies for obtaining protein concentrates from tambacu filleting residues, characterize their physicochemical composition and evaluate their sensory profile.

\section{Material and Methods}

Development of tambacu protein concentrates

Ground meat from tambacu (Colossoma macropomum $\times$ Piaractus mesopotamicus) filleting shavings was acquired from a local business which markets this frozen product.

Fish protein concentrates (FPC) were elaborated using three different processes, with three replicates per methodology:

\section{Methodology 1 (FPC1)}

The ground tambacu shavings were cooked for $60 \mathrm{~min}$ in pressure cookers. Soon after, the material was pressed in a manual press and the press pie was ground in a multiprocessor (Philips Walita, São Paulo, Brazil). The resulting mass was dehydrated in a forced ventilation oven (Tecnal, São Paulo, Brazil) for $20 \mathrm{~h}$ at $60{ }^{\circ} \mathrm{C}$. At the end of this process, a new grinding was performed, followed by sieving (Souza et al., 2017).

\section{Methodology 2 (FPC2)}

Ground tambacu shavings were cooked for $60 \mathrm{~min}$ in pressure cookers. After that, the material was pressed into a manual press and the press pie was ground in a multiprocessor (Philips Walita, São Paulo, 
Brazil). The resulting mass was dehydrated in a forced ventilation oven (Tecnal, São Paulo, Brazil) for $20 \mathrm{~h}$ at $60^{\circ} \mathrm{C}$. After drying, a process was carried out to delipidify the protein concentrate, which consisted of three washes with ethanol at $70{ }^{\circ} \mathrm{C}$, in the proportion of $4: 1$ (ethanol:raw material). Each wash lasted 20 min, and between the washes, ethanol was discarded through filtration. After washing, the protein concentrate was dried in a forced ventilation oven for $2 \mathrm{~h}$ at $60^{\circ} \mathrm{C}$. At the end of this process, a new grinding was performed, followed by sieving.

\section{Methodology 3 (FPC3)}

The shavings of ground tambacu went through a process of three washes with ethanol at $70^{\circ} \mathrm{C}$, each lasting $20 \mathrm{~min}$, in the proportion of 3:1 (ethanol:raw material). Between washes, the raw materials were pressed with the aid of a manual press. After final pressing, the press pie was ground into a multiprocessor (Philips Walita, São Paulo, Brazil). The resulting mass was dehydrated in a forced ventilation oven (Tecnal, São Paulo, Brazil) for $20 \mathrm{~h}$ at $60^{\circ} \mathrm{C}$. At the end of this process, a new grinding was performed, followed by sieving.

\section{Determination of the yield of the processes}

At the end of each stage of the process of preparing protein concentrates, the raw materials were weighed to determine weight losses during processing; the final yield of tambacu protein concentrates prepared by different methodologies was also measured. The yield of the process was determined as the relationship between the final weight of protein concentrate $(\mathrm{g})$ and the initial weight of tambacu shavings (g), expressed as a percentage, according to Equation 1.

Yield $(\%)=\frac{\text { Weight at the end of each stage }(\mathrm{g})}{\text { Initial weight }(\mathrm{g})} \times 100$

\section{Analysis of proximal composition}

The moisture, protein, lipid and ash content of the raw material and protein concentrates was determined in triplicate, according to the methodology of the Association of Official Analytical Chemists [AOAC] (2005).

\section{Analysis of water activity, colour and $\mathrm{pH}$}

The water activity of the raw material and protein concentrates was determined using an Aqualab appliance (Legacy AQUALAB Series 3, METER Group, WA, USA).

The colouration of the raw material and protein concentrates was determined in triplicate, taking three different reading points per sample. A colorimeter (Konica Minolta, Tokyo, Japan) was used, at an angle of $90^{\circ}$ and at room temperature, obtaining the luminosity values $L^{*}\left(L^{*}=0\right.$ black and $L^{*}=100$ white), chroma $a^{*}$ (red-green component) and chroma $b^{*}$ (yellow-blue component).

To determine the $\mathrm{pH}, 10 \mathrm{~g}$ of sample was diluted and homogenized in $90 \mathrm{~mL}$ of distilled water. The $\mathrm{pH}$ of this mixture was measured using a pHmetro electrode (Testo 205, Testo Limited, Hampshire, UK) (Instituto Adolfo Lutz [IAL], 1985). 
Sensory analysis

Sensory analysis was performed with 15 semi-trained tasters to evaluate the characteristics of FPC. The sensory analysis was approved by the Standing Committee on Ethics in Research with Human Beings of the Universidade Estadual de Maringá, Maringá PR Brazil (Protocol CAAE: 14219213.1.0000.0104). The three tambacu protein concentrates were presented in disposable plastic cups, sealed with plastic film and identified with three random numbers. The attributes of colour, odour and fish flavour of protein concentrates were evaluated using a labelled magnitude sensory scale, as proposed by Green et al. (1996). A sensory analysis form using a labelled magnitude sensory scale was constructed by means of the geometric means of the estimated magnitudes of six semantic descriptors. Scale used for fish odour and flavour: 'almost undetectable' $=0.3 \mathrm{~cm}$; 'weak' $=1.2 \mathrm{~cm}$; 'moderate' $=3.4 \mathrm{~cm}$; 'strong' $=7.1 \mathrm{~cm}$; 'very strong' $=10.7 \mathrm{~cm}$; 'as strong as possible' $=20 \mathrm{~cm}$. Scale used for colour: 'very dark' = $0.3 \mathrm{~cm}$; 'dark' = $1.2 \mathrm{~cm}$; 'moderately dark' = 3.4 cm; 'light' $=7.1 \mathrm{~cm}$; 'very light' $=10.7 \mathrm{~cm}$; 'as clear as possible' $=20 \mathrm{~cm}$.

\section{Statistical analysis}

All data were submitted to analysis of variance (ANOVA) at a level of $5 \%$ significance, using Statistica 7.1 software. In the case of differences ( $P<0.05)$, the Tukey test was applied to compare the means. The data were expressed as the mean \pm standard error.

\section{Results and Discussion}

The yields obtained during the stages of processing protein concentrates can be observed in Figure 1. For the protein concentrate obtained by cooking the raw material and subsequent drying (FPC1), it can be verified that after pressing, the yield dropped to $50.5 \%$ and the final drying step decreased the yield to $18.6 \%$. For the raw material that was washed with ethanol at 70 ${ }^{\circ} \mathrm{C}$ and subsequently dried (FPC3), between washes the yield decreased from $59.0 \%$ to $46.1 \%$, and after drying, it was decreased to $19.8 \%$, a yield that did not differ $(P>0.05)$ from that of FPC1. The method of cooking, drying, delipidification with hot ethanol and subsequent drying (FPC2) showed the lowest $(P<0.05)$ final yield of $15.5 \%$. 
(a)

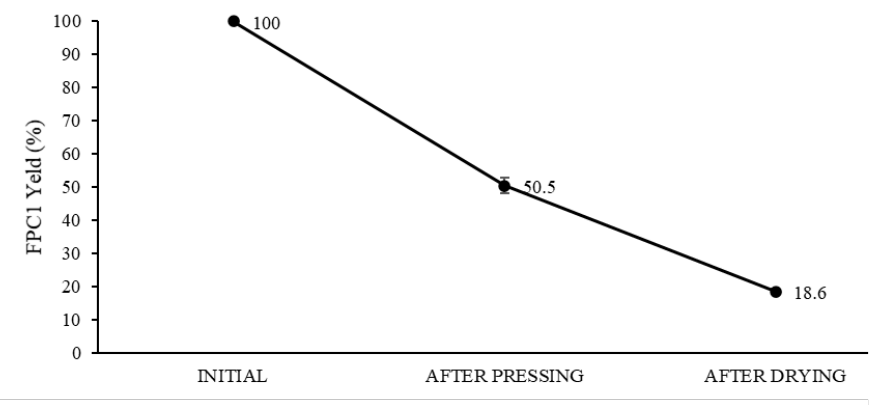

(c)

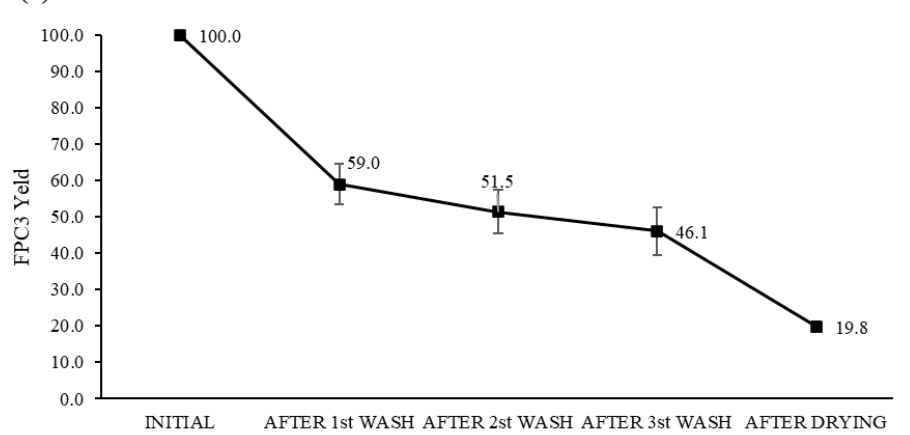

(b)

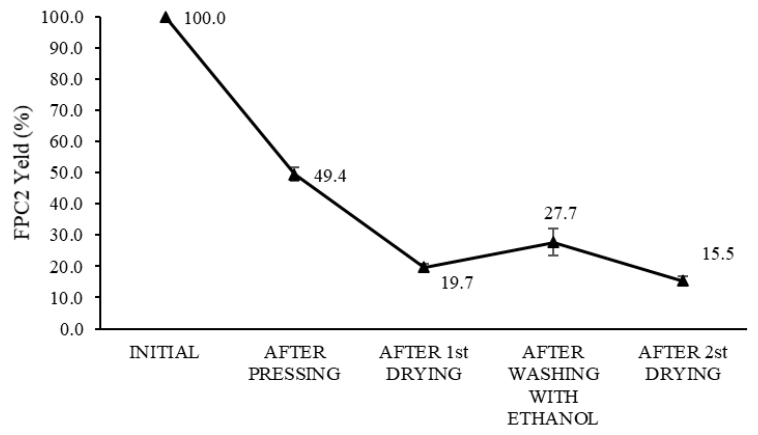

(d)

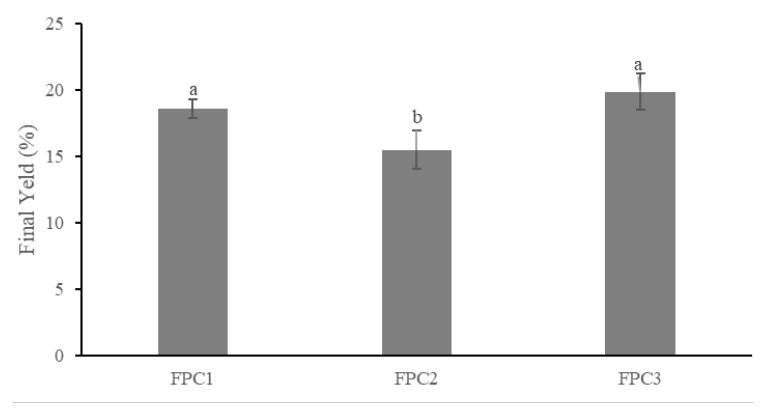

Figure 1. Processing yields of tambacu protein concentrates prepared by different methodologies. (a) FPC1: cooking and subsequent drying; (b) FPC2: cooking, drying, delipidification with hot ethanol and subsequent drying; (c) FPC3: washing with hot ethanol and subsequent drying; (d) Final yields of fish protein concentrates. Different capital letters indicate a significant difference $(P=0.0120)$ between the final yields of the different concentrates. Vertical bars indicate the standard error of the mean.

The yield of tambacu protein concentrates varied in relation to the method used to their obtation; cooking the shavings and later drying (FPC1) generated a yield similar to that found for FPC3 (successive washing of the raw material with hot ethanol), and this yield was higher than that found for FPC2 (cooking, drying, delipidification with hot ethanol and later drying). Probably, more weight was lost in FPC2 due to the higher number of processes involved in its elaboration. Usually, a higher yield of protein concentrate indicates a method providing a more economic result (Asfar, Tawali, Abdullah,
\& Mahendradatta, 2014). Ibrahim (2009) produced a protein concentrate from tilapia residues and observed that its yield was $13.64 \%$ of the final raw material. In FPC from ribbon fish (Lepturacanthus savala), the FPC yield from five extraction methods ranged from 17.54-19.94\% (Akhade et al., 2016), which were similar to those found in this study.

In the proximal composition of tambacu protein concentrates (Table 1), differences $(P<0.05)$ can be observed between the concentrates for moisture, protein and lipid content. The moisture content was lower in the protein concentrate submitted to cooking 
of the raw material and subsequent drying (FPC1), while the highest moisture content was observed in the protein concentrate obtained by cooking, drying, delipidification with hot ethanol and final drying (FPC2). FPC2 had the highest protein content (80.39\%) and lowest average lipid content (2.47\%), compared to the others $(P<0.05)$. FPC1 had the lowest protein content (71.95\%) and highest lipid content (23.57\%), while FPC3 (obtained by washing the raw material with hot ethanol and subsequent drying) presented values intermediate to those for FPC1 and FPC2. The ashes content was not different among the concentrates, ranging from $4.25 \%$ to $6.29 \%$.

\section{Table 1}

\section{Centesimal composition of tambacu protein concentrates prepared by different methodologies}

\begin{tabular}{lccccc} 
Parameters & In natura tambacu & \multicolumn{3}{c}{ Protein concentrates } & \multirow{2}{*}{ P } \\
\cline { 3 - 5 } & filleting residues & FPC1 & FPC2 & FPC3 & \\
Moisture & $71.29 \pm 0.93$ & $3.15 \pm 0.24 \mathrm{~b}$ & $5.22 \pm 0.47 \mathrm{a}$ & $4.63 \pm 0.01 \mathrm{ab}$ & 0.0223 \\
Protein & $20.65 \pm 0.74$ & $71.95 \pm 1.02 \mathrm{c}$ & $80.39 \pm 0.27 \mathrm{a}$ & $76.75 \pm 0.69 \mathrm{~b}$ & 0.0008 \\
Lipids & $8.00 \pm 2.43$ & $23.57 \pm 0.55 \mathrm{a}$ & $2.47 \pm 0.33 \mathrm{c}$ & $14.09 \pm 0.48 \mathrm{~b}$ & $<0.0001$ \\
Ashes & $1.79 \pm 0.04$ & $4.25 \pm 0.08$ & $4.98 \pm 0.31$ & $6.29 \pm 0.62$ & 0.0706
\end{tabular}

Data expressed as average \pm standard error. Averages followed by distinct letters differ from each other by the Tukey test. FPC1: cooking and subsequent drying; FPC2: cooking, drying, delipidification with hot ethanol and subsequent drying; FPC3: washing with hot ethanol and subsequent drying.

Chemical analysis of fish and derived products is important because it provides useful information for researchers interested in developing protein-rich foods, ensuring their best quality, flavour, colour, odour, texture and safety for consumers (Jabeen \& Chaudhry, 2011).

The shavings are considered a byproduct of filleting; they are obtained by removing flaps from the fillet in the process stage called 'toillet', in order to remove remaining bones, standardize the size and remove imperfections (Oetterer, 2002). Due to their taste, appearance, number of bones, fat content and other sensory attributes, shavings do not have a high degree of acceptability for consumption in their original form (Minozzo,
Waszczynskyj, \& Boscolo, 2009), but are a good raw material for fish products (Bordignon et al., 2010). In the present study, tambacu shavings presented $71.29 \%$ moisture, $20.65 \%$ protein, $8 \%$ lipids and $1.79 \%$ ashes, values similar to those reported by Reis et al. (2020) for tambacu fillets, which were $19.98 \%$ protein, $11,76 \%$ lipids and $1.27 \%$ ash.

The methodology for obtaining FPC will determine their proximal composition, mainly in relation to protein and lipid content. In the present study, it can be observed that cooking followed by delipidification with ethanol (FPC2) was more effective than successive washes of the raw material with hot ethanol (FPC3), since FPC2 presented a higher crude protein content and lower lipid content than the others. This 
might be due to the previous cooking of the raw material, facilitating the removal of lipids and promoting the hydrophilicity (tendency to absorb water) of the protein concentrate (Cândido et al., 1998). In addition, heating promotes the denaturation and coagulation of meat proteins (Machado, 2011). In the production of an FPC, the increase in protein content occurs through the extraction of lipids from the raw material, which can be done by extraction in alkaline medium or by treatment with organic solvents such as isopropanol or ethanol which favour dehydration (Cândido et al., 1998). The process removes the fat and other substances responsible for the fish flavour and aroma (Ordóñez et al., 2005). In this study, previous cooking was fundamental for lipid extraction, providing a concentrate with a lower lipid content and higher protein content. This information is also important in relation to ethanol consumption, since the use of organic solvents in the production of protein concentrates tends to increase the final product yield and, in the development of FPC2, 80\% less ethanol was used than for the preparation of FPC3. Nevertheless, the final yield of FPC2 was $4.5 \%$ lower than that of FPC3, probably due to losses after cooking combined with subsequent washes with ethanol. In a study comparing different methods of obtaining FPC from ribbon fish (Lepturacanthus savala), the Canadian process for obtaining FPC, which combines the acidification of the raw material with phosphoric acid, cooking, and subsequent treatment with isopropyl alcohol, was more efficient for obtaining an FPC with a low lipid content (Akhade et al., 2016).

In this study, the method used in FPC3 was not efficient for the complete removal of lipids, which can be attributed to the raw material not having been submitted to an initial extraction of lipids with cold ethanol, as recommended by Ordóñez et al. (2005). These authors state that to produce a type A protein concentrate, the first treatment must be cold solvent for at least $50 \mathrm{~min}$; hot solvent (up to $75^{\circ} \mathrm{C}$ ) is used in the following two extraction steps.

Leaving the raw material in contact with the solvent for longer could be an alternative to increasing the efficiency of lipid removal in the FPC. To produce protein concentrates from skipjack (Katsuwonus pelamis) roes, defatting methods using isopropyl alcohol and ethanol with extraction times of 1,2 , and 3 hours were used, and the most efficient method used isopropyl alcohol for 3 hours (Rieuwpassa, Santoso, \& Trilaksani, 2013).

An inverse relationship between lipid content and moisture in fish (Ogawa \& Maia, 1999) was also observed in the protein concentrates developed in this study. The protein concentrate submitted only to cooking and drying (FPC1) presented a higher lipid content and lower moisture content, and the opposite was observed in FPC2, which presented a higher moisture content and lower lipid content.

Regarding the ashes content (mineral matter) of protein concentrates, the absence of a significant difference between the means is possibly due to ethanol treatments being effective for the removal of lipids, but not of bone residues naturally present in tambacu shavings. When the shavings do not pass through a debonig machine, they may contain ground bones or a series of bones (Bordignon et al., 2010), which in the analysis of the centesimal proximal are expressed as ashes.

FPC1, because it has not undergone a process of delipidification, can be considered a type $\mathrm{C}$ protein concentrate, characterized by 
being a non-deodorized flour without limits for fat and with a minimum of $60 \%$ protein (Ordóñez et al., 2005). Non-deodorized flours produced from tilapia, salmon, tuna and sardine residues were developed by Souza et al. (2017), using a methodology similar to that used in this study to obtain FPC1. For these flours, the authors obtained between $1.78 \%$ and $4.86 \%$ moisture, from $51.13 \%$ to $83.28 \%$ protein, from $3.98 \%$ to $18.81 \%$ lipids and $5.31 \%$ to $37.66 \%$ ash (Souza et al., 2017). These high variations were explained using different raw materials, as carcasses of tilapia and salmon, tuna torsos without fins, and sardine tails were used (Souza et al., 2017). In the present study, shavings from the tambacu fillet were used, and there was no defatting step in the methodology for obtaining FPC1, explaining its similarity to the original raw material.
Due to the characteristics of the concentrates obtained, FPC2 can be considered a type $\mathrm{B}$ protein concentrate, which has up to $3 \%$ lipids (Oetterer, 2002; Ordóñez et al., 2005). Despite having gone through the process of delipidification, FPC3 cannot be classified as type A, B or $\mathrm{C}$, due to its chemical characteristics and the process for obtaining not being fully effective for lipid removal.

Table 2 shows the $\mathrm{pH}$ and water activity of the raw material and protein concentrates. For both parameters, no differences were observed $(P>0.05)$ between concentrates. The $\mathrm{pH}$ ranged from 6.48 (FPC2) to 6.57 (FPC3), and water activity ranged from 0.26 (FPC2) to 0.30 (FPC3). The in natura tambacu filleting residues presented an average $\mathrm{pH}$ of 6.32 and water activity of 0.97 .

Table 2

Centesimal composition of tambacu protein concentrates prepared by different methodologies

\begin{tabular}{cccccc} 
Parameters & In natura tambacu & \multicolumn{3}{c}{ Protein concentrates } & P \\
\cline { 3 - 5 } & shavings & FPC1 & FPC2 & FPC3 & \\
pH & $6.32 \pm 0.01$ & $6.52 \pm 0.02$ & $6.48 \pm 0.03$ & $6.57 \pm 0.03$ & 0.1357 \\
$\mathrm{Aa}$ & $0.97 \pm 0.00$ & $0.27 \pm 0.02$ & $0.26 \pm 0.02$ & $0.30 \pm 0.01$ & 0.5544
\end{tabular}

Data expressed as average \pm standard error. FPC1: cooking and subsequent drying; FPC2: cooking, drying, delipidification with hot ethanol and subsequent drying; FPC3: washing with hot ethanol and subsequent drying.

The mean $\mathrm{pH}$ found in shavings and protein concentrates (between 6.32 and 6.57) shows that they are low-acid foods $(\mathrm{pH}$ $>4.5)$. In fact, in natura fish present $\mathrm{pH}$ values close to neutrality (Ogawa \& Maia, 1999) and water activity close to 1 , and fish have a water activity higher than 0.95 (Pedro \& Nunes, 2011), corroborating the findings in this study for tambacu shavings. $\mathrm{pH}$ is a major factor because it limits the possibility of developing microorganisms in food (Fernandes, Oliveira, Souza, \& Lopes, 2013). According to Ferreira, Figueirêdo, \& Queiroz (2005), no microorganism grows in a completely dry medium, needing water to develop its functions, and most microorganisms grow in a medium with a water activity of between 0.90 and 0.99 . The drying of protein concentrates, in addition to reducing moisture, decreased their water activity, to values close to that 
observed in vegetable flours, which is between 0.2 and 0.4 (Syamaladevi et al., 2016). Water activity equal to 0.60 is considered to be the minimum limit capable of allowing the development of microorganisms, hence the fact that dehydrated foods, such as flours, are considered microbiologically stable (Fernandes et al., 2013). A low water activity reflects a longer product life and helps limit migration of moisture within a food product made with different ingredients (Abbas, Saleh, Mohamed, \& Lasekan, 2009).
In the colour analysis of tambacu protein concentrates (Table 3), differences were observed between the methods used to prepare concentrates $(P<0.05)$ for the three components analysed (luminosity, chroma $a^{*}$ and chroma $\left.b^{*}\right)$. FPC2 presented the highest luminosity (74.97), and lower averages for chroma $a^{*}(1.77)$ and chroma $b^{*}(14.12)$ in relation to the other concentrates. FPC1 presented the lowest luminosity (60.57) and highest intensity of red - chroma $a^{*}(4.24)$. FPC3 was the concentrate with the yellowest colour (chroma b*: 18.59).

\section{Table 3}

\section{Colour of tambacu protein concentrates prepared by different methodologies}

\begin{tabular}{cccccc} 
Parameters & In natura tambacu & \multicolumn{3}{c}{ Protein concentrates } & \multirow{2}{*}{ Phavings } \\
\cline { 3 - 5 } & $47.62 \pm 2.57$ & $60.57 \pm 1.02 \mathrm{c}$ & $74.97 \pm 1.19 \mathrm{a}$ & $69.68 \pm 0.38 \mathrm{~b}$ & 0.0010 \\
\cline { 3 - 5 } $\mathrm{L}^{*}$ & $3.72 \pm 0.37$ & $4.24 \pm 0.07 \mathrm{a}$ & $1.77 \pm 0.32 \mathrm{c}$ & $2.82 \pm 0.09 \mathrm{~b}$ & 0.0003 \\
$\mathrm{a}^{*}$ & $7.02 \pm 0.65$ & $16.84 \pm 0.03 \mathrm{~b}$ & $14.12 \pm 0.34 \mathrm{c}$ & $18.59 \pm 0.05 \mathrm{a}$ & $<0.0001$ \\
$\mathrm{~b}^{*}$ & &
\end{tabular}

Data expressed as average \pm standard error. Averages followed by different letters differ from each other by the Tukey test $(P<0.05)$. FPC1: cooking and subsequent drying; FPC2: cooking, drying, delipidification with hot ethanol and subsequent drying; FPC3: washing with hot ethanol and subsequent drying.

Colour influences the general acceptance of food products (Foh, Kamara, Amadou, Foh, \& Wenshui, 2011). For FPC, the highest quality is associated with more whitish staining, characteristic of type $A$ protein concentrates, which have less than 0.75\% lipids (Ordóñez et al., 2005). The colour of fish meat depends on the content of red muscles and oxidative changes in muscle haemoproteins - myoglobin, haemoglobin and cytochromes (Sikorski \& Kotakowski, 2016). Protein concentrates with a darker colour are due to their lipid content, because fat causes a darker colour to occur, resulting from techniques that do not use organic solvents
(Ordóñez et al., 2005). In the present study, the luminosity of protein concentrates was related to the lipid content of the product, since FPC2, with a lower lipid content, presented higher luminosity (more whitish) than the others. FPC1 was the darkest and most red among the concentrates. This instrumental colouration was perceived in the sensory analysis, where the tasters attributed a colour between 'moderately dark' and 'light', being considered darker than FPC2.

In the sensory analysis of tambacu protein concentrates (Table 4), significant differences were observed $(P<0.05)$ for the 
three parameters analysed (odour, colour and fish flavour). FPC1 presented the strongest odour, the darkest colour and the strongest fish flavour in relation to the others. For odour and colour, FPC2 and FPC3 concentrates presented equal means, and for odour the means were 1.21 and $1.90 \mathrm{~cm}$, respectively, values close to the $1.2 \mathrm{~cm}$ marker (weak odour). For colour, the means for FPC2 and FPC3 were 9.25 and $7.46 \mathrm{~cm}$, respectively, values close to the light $(7.1 \mathrm{~cm})$ and very light $(10.7$ $\mathrm{cm})$ markers. For fish flavour, FPC2 presented the lowest average $(1.75 \mathrm{~cm})$, a value close to the $1.2 \mathrm{~cm}$ marker that indicated 'weak' fish flavour. For the fish flavour parameter, the average of $6.73 \mathrm{~cm}$ for FPC3 was close to the $7.1 \mathrm{~cm}$ marker, which indicated a 'strong' fish flavour.

\section{Table 4}

\section{Sensory analysis of tambacu protein concentrates prepared by different methodologies}

\begin{tabular}{|c|c|c|c|c|}
\hline \multirow{2}{*}{ Parameters } & \multicolumn{3}{|c|}{ Protein concentrates } & \multirow{2}{*}{$P$} \\
\hline & FPC1 & FPC2 & FPC3 & \\
\hline Odour $(\mathrm{cm})^{1}$ & $7.65 \pm 1.20 \mathrm{a}$ & $1.21 \pm 0.27 b$ & $1.90 \pm 0.35 b$ & $<0.0001$ \\
\hline Colour $(\mathrm{cm})^{2}$ & $5.31 \pm 0.63 b$ & $9.25 \pm 1.13 a$ & $7.46 \pm 0.57 \mathrm{ab}$ & 0.0058 \\
\hline Fish flavour $(\mathrm{cm})^{1}$ & $10.45 \pm 1.33 a$ & $1.75 \pm 0.44 c$ & $6.73 \pm 0.91 b$ & $<0.0001$ \\
\hline
\end{tabular}

Data expressed as average \pm standard error. Averages followed by distinct letters differ from each other by the Tukey test. FPC1: cooking and subsequent drying; FPC2: cooking, drying, delipidification with hot ethanol and subsequent drying; FPC3: washing with hot ethanol and subsequent drying. 'Scale used: 'almost undetectable' $=0.3 \mathrm{~cm}$; 'weak' = $1.2 \mathrm{~cm}$; 'moderate' = $3.4 \mathrm{~cm}$; 'strong' = $7.1 \mathrm{~cm}$; 'very strong' = $10.7 \mathrm{~cm}$; 'as strong as possible' $=20 \mathrm{~cm}$. ${ }^{2}$ Scale used: 'very dark' = 0.3 cm; 'dark' = $1.2 \mathrm{~cm}$; 'moderately dark' = $3.4 \mathrm{~cm}$; 'light' = $7.1 \mathrm{~cm}$; 'very light' = $10.7 \mathrm{~cm}$; 'as clear as possible' = $20 \mathrm{~cm}$.

The smell of fresh fish is caused by numerous volatile organic components present in tissues in very small concentrations, generated in the processes of enzymatic degradation of lipids and nitrogen components (Sikorski \& Kotakowski, 2016). Thus, species with a high fat content promote the development of intense aromas in elaborated products (Oetterer, 2001). This was confirmed in the present study, where FPC1, which did not go through the delipidification process, presented a significantly stronger odour than the other concentrates.

Therefore, the concentrate obtained through the cooking method (FPC1) presented a powder with a darker colour in relation to the others, a more intense odour and finally with the highest fish flavour. With these sensory characteristics, its addition would only be acceptable in fish-based prepared foods (Jesus \& Almeida, 2011; Ordóñez et al., 2005). The odour of the concentrate produced using the method consisting of cooking, drying, delipidification with hot ethanol and subsequent drying (FPC2) was considered 'weak', and it had a weak fish flavour, being, therefore, a concentrate that can be added to various products without altering their sensorial characteristics (Ordóñez et al., 2005). FPC3 had a light-yellow colour, with very weak fish odour; however, it has a fish flavour, which can be attributed its fat content. 
To obtain a concentrate product with a high protein content and low lipid content (type A), the raw material has to go through a delipidification methodology with ethanol or other solvents; this methodology has to be adapted, because in this study, the methodology used in FPC3 was not efficient for the complete removal of lipids. Despite having gone through the process of delipidification, FPC3 cannot be classified as type $A, B$ or $C$, due to its chemical characteristics and the process for obtaining it not being fully effective for the lipid removal. The most effective methodology in this study was FPC2, which included the delipidification process after pre-cooking; this previous cooking was fundamental for the extraction of lipids, providing a concentrate with lower lipid content and higher protein content, a type B concentrate. The concentrate produced only by cooking (FPC1) had values corresponding to a type $\mathrm{C}$ concentrate, as the lipids were not removed.

\section{Conclusion}

The method of delipidification with ethanol at $70^{\circ} \mathrm{C}$, performed after cooking and drying of the raw material (FPC2), was more effective for lipid removal and deodorisation of tambacu shavings, producing a protein concentrate with a higher protein content, lower lipid content, lighter colour, and weaker fish flavour than concentrates prepared by cooking the raw material with subsequent drying (FPC1) and three washing steps with ethanol at $70^{\circ} \mathrm{C}$ and drying (FPC3).

This study demonstrated the feasibility of producing protein concentrates from tambacu filleting residues using a methodology with a lower solvent volume, generating a product with a high protein content that is effective for the nutritional enrichment of various food products.

\section{References}

Abbas, K.A.,Saleh,A.M.,Mohamed,A.,\&Lasekan, O. (2009). The relationship between water activity and fish spoilage during cold storage: a review. Journal of Food, Agriculture \& Environment, 7(3/4), 86-90. Retrivied from https://www.researchgate. net/publication/237356312_The_ relationship_between_water_activity_ and_fish_spoilage_during_cold_ storage_A_review

Akhade, A. R., Koli, J. M., Sadawarte, R. K., \& Akhade, R. R. (2016). Functional properties of fish protein concentrate extracted from ribbon fish, Lepturacanthus savala by different methods. International Journal of Processing and Post Harvest Technology, 7(2), 1-9. doi: 10.15740/HAS/ IJPPHT/7.2/1-9

Asfar, M., Tawali, A. B., Abdullah, N., \& Mahendradatta, M. (2014). Extraction of albumin of snakehead fish (Channa striatus) in producing the fish protein concentrate (FPC). International Journal of Scientific \& Technology Research, 3(4), 85-88. Retrivied from http://www. ijstr.org/final-print/apr2014/ExtractionOf-Albumin-Of-Snakehead-Fish-channaStriatus-In-Producing-The-Fish-ProteinConcentrate-fpc.pdf

Associação Brasileira da Piscicultura (2021). Anuário Peixe BR da Piscicultura 2021. São Paulo: Peixe BR. Recuperado de https:// www.peixebr.com.br/anuario-2021/

Associations of Official Analytical Chemists (2005). Official methods of analyses of the association of analytical chemists. Washington, DC: AOAC. 
Bordignon, A. C., Souza, B. E., Bohnenberger, L., Hilbig, C. C., Feiden, A., \& Boscolo, W. R. (2010). Elaboração de croquete de tilápia do Nilo (Oreochromis niloticus) a partir de CMS e aparas do corte em ' $V$ ' do filé e sua avaliação físico-química, microbiológica e sensorial. Acta Scientiarum. Animal Sciences, 32(1), 109-116. doi: 10.4025/ actascianimsci.v32i1.6909

Cândido, L. M. B., Nogueira, A. K., \& Sgarbieri, V. (1998). Propriedades funcionais de concentrados proteicos de pescado preparados por vários métodos. Brasilian Journal of Food Tecnology, 1(1/2), 77-89.

Coradini, M. F., Souza, M. L. R., Verdi, R., Goes, E. S. D. R., Kimura, K. S., \& Gasparino, E. (2015). Quality evaluation of onion biscuits with aromatized fishmeal from the carcasses of the Nile tilapia. Boletim do Instituto de Pesca, 41(Esp.), 719-728. Retrieved from https://www.pesca.sp.gov.br/boletim/ index.php/bip/article/view/1098/1075

Dao, V. T., \& Kim, J. K. (2011). Scaled-up bioconversion of fish waste to liquid fertilizer using a $5 \mathrm{~L}$ ribbon-type reactor. Journal of Environmental Management, 92(10), 2441-2446. doi: 10.1016/j. jenvman.2011.05.003

Fernandes, H. R., Oliveira, D. C. R., Souza, G. S., \& Lopes, A. S. (2013). Parâmetros de qualidade física e físico-química da farinha de mandioca (Manihot esculenta Crantz) durante processamento. Scientia Plena, 9(11), 111501-1. Recuperado de https://www.scientiaplena.org.br/sp/ article/view/1615/917

Ferreira, C. J., Neto, Figueirêdo, R. M. F., \& Queiroz, A. J. M. (2005). Avaliação sensorial e da atividade de água em farinhas de mandioca temperadas. Ciência e Agrotecnologia, 29(4), 795-802. doi: 10.1590/ S1413-70542005000400011
Foh, M. B. K., Kamara, M. T., Amadou, I., Foh, B. M., \& Wenshui, X. (2011). Chemical and physicochemical properties of tilapia (Oreochromis niloticus) fish protein hydrolysateand concentrate. International Journal of Biological Chemistry, 5(1), 2136. doi: 10.3923/ijbc.2011.21.36

Fonseca, C., Frare, L. M., D'Avila, L., \& Edwiges, T. (2020). Influence of different waste compositions from tilapia fish on methane production. Journal of Cleaner Production, 265(2020), 121795. doi: 10. 1016/j.jclepro.2020.121795

Green, G. B., Dalton, P., Cowart, B., Shaffer, G., Rankin, K., \& Higgins, J. (1996). Evaluating the 'Labeled Magnitude Scale'for measuring sensations of taste and smell. Chemical Senses, 21(3), 323-334. doi: 10. 1093/chemse/21.3.323

Ibrahim, S. M. (2009). Evaluation of production and quality of salt-biscuits supplemented with fish protein concentrate. World Journal of Dairy and Food Sciences, 4(1), 28-31. doi: Retrieved from http:// citeseerx.ist.psu.edu/viewdoc/download ?doi=10.1.1.600.6029\&rep=rep1\&type $=p$ $\mathrm{df}$

Ikasari,D.,\&Wijaya,M.I.(2021).Physicochemical properties of snakehead (Channa striata) fish protein concentrate extracted by different methods. AIP Conference Proceedings, 2349(1), 020037. doi: 10.10 $63 / 5.0051833$

Instituto Adolfo Lutz (1985). Normas analíticas doinstituto Adolfo Lutz: métodos químicos e físicos para análise de alimentos (2a ed.). São Paulo: Instituto Adolfo Lutz.

Instituto Brasileiro de Geografia e Estatística (2016). Produção da pecuária municipal 2016. Rio de Janeiro: IBGE. 
Jabeen, F., \& Chaudhry, A. S. (2011). Chemical compositions and fatty acid profiles of three freshwater fish species. Food Chemistry, 125(3), 991-996. doi: 10.1016/j.foodchem.2010.09.103

Jesus, R., \& Almeida, J. C. (2011). Concentrado proteico de pescado. In A. A. Gonçalves (Ed.), Tecnologia do pescado: ciência, tecnologia, inovação e legislação (pp. 382-383). São Paulo: Atheneu.

Machado, T. M. (2011). Embutidos de pescado. In A. A. Gonçalves (Ed.), Tecnologia do pescado: ciência, tecnologia, inovação e legislação (pp. 382-383). São Paulo: Atheneu.

Minozzo, M. G., Waszczynskyj, N., \& Boscolo, W. R. (2009). Utilização de carne mecanicamente separada de tilápia (Oreochromis niloticus) para a produção de patês cremoso e pastoso. Alimentos e Nutrição Araraquara, 19(3), 315-319. doi: Recuperado de https://serv-bib. fcfar.unesp.br/seer/index.php/alimentos/ article/view/636

Monteiro, M. L. G., Mársico, E. T., Lázaro, C. A., Ribeiro, R. O., Jesus, R. S., \& Conte, C. A., Jr. (2014). Flours and instant soup from tilapia wastes as healthy alternatives to the food industry. Food Science and Technology Research, 20(3), 571-581. doi: 10.3136/fstr.20.571

Oetterer, M. (2001). Produtos obtidos por interferência na fração proteica do pescado. Piracicaba: ESALQ.

Oetterer, M.(2002).Industrializaçãodopescado cultivado. Guaiba: Ed. Agropecuária.

Oetterer, M., Galvão, J. A., \& Sucasas, L. F. A. (2014). Sustentabilidade na cadeia produtiva do pescado: aproveitamento de resíduos. In A. J Galvão, \& M. Oetterer (Eds.), Qualidade e processamento de pescado (pp. 97-118). Rio de Janeiro: Elsevier Brasil.
Ogawa, M., \& Maia, E. L. (1999). Manual de pesca. São Paulo: Livraria Varela.

Ordóñez, J. A., Rodrigues, C. I. M., Álvarez, F. L., Sanz, G. L. M., Minguillón, F. G. G., Perales, H. L., \& Cortecero, S. D. M. (2005). Tecnologia de alimentos: alimentos de origem animal. Porto Alegre: Artmed.

Pedro, S., \& Nunes, L. M. (2011). Secagem do pescado. In A. A. Gonçalves (Ed.), Tecnologia do pescado: ciência, tecnologia, inovação e legislação (pp. 149-150). São Paulo: Atheneu.

Reis, R. V., Neto, Hashimoto, D. T., Corrêa, C. F., Enke, D. B. S., Gervaz, W. R., \& Lattanzi, G. R. (2020). Performance of tambacu hybrid (ô Piaractus mesopotamicus $x \propto$ Colossoma macropomum) and its parental pacu (Piaractus mesopotamicus) evaluated in cages under different feeding programmes. Aquaculture Reports, 17(2020), 100355. doi: 10.1016/j. aqrep.2020.100355

Rieuwpassa, F. J., Santoso, J., \& Trilaksani, W. (2013). Characterization of functional properties fish protein concentrate of skipjack roe (Katsuwonus pelamis). Jurnal IImu dan Teknologi Kelautan Tropis, 5(2), 299-309. doi: 10.29244/jitkt.v5i2.7559

Sikorski,Z.E., \& Kotakowski, E. (2016).3Seafood quality issues. In E. G. DaczkowskaKozon, \& B. S. Pan, Environmental effects on seafood availability, safety, and quality (pp. 29-47). Boca Raton: CRC Press.

Souza, J. F., Bittencout, N. N., Gomes, C. S., Oliveira, J. K., Santos, R. M., Reis, I. A. O.,... Narain, N. (2010). Desenvolvimento e caracterização físico-química e sensorial de nuggets formulados com concentrado proteico de pescadoMARINE BEEF. Scientia Plena, 6(3), 031501-1. Recuperado de https://www. scientiaplena.org.br/sp/article/view/140 
Souza, M. L. R., Yoshida, G. M., Campelo, D. A. V., Moura, L. B., Xavier, T. O., \& Goes, E. S. R. (2017). Formulation of fish waste meal for human nutrition. Acta Scientiarum Technology, 39(5), 525-531. doi: 10.4025/ actascitechnol.v39i5.29723

Syamaladevi, R. M., Tadapaneni, R. K., Xu, J., Villa-Rojas, R., Tang, J., Carter, B.,... Marks, B. (2016). Water activity change at elevated temperatures and thermal resistance of Salmonella in all purpose wheat flour and peanut butter. Food Research International, 81(2016), 163170. doi: 10.1016/j.foodres. 2016.01.008
Trinh, S., Nguyen, L., Le, T., \& Le, H. (2017). Production of fish protein concentrate (FPC) from Palgasius Catfish and study on the effect of sodium chloride, sodium tripolyphosphate, sucrose and sorbitol to the protein solubility and water holding capacity of FPC. Science and Technology Development Journal - Natural Sciences, 1(T1), 86-95. doi: 10.32508/stdjns.v1iT1. 439

Vidotti, R. M. (2011). Silagem do pescado. In A. A. Gonçalves (Ed.), Tecnologia do pescado: ciência, tecnologia, inovação e legislação (pp. 401). São Paulo: Atheneu. 
